\title{
社会的比較によって生じる感情や行動の発達的変化 ${ }^{1)}$ —ーパーソナリティ特性との関連性に焦点を当てて
}

\author{
外山美 樹
}

東京成徳大学・日本学術振興会

本研究の目的は, 小学 4 年生, 6 年生ならびに中学 2 年生を対象とし, 社会的比較を行った後, その個人 に生じる感情や行動について発達的に検討すること, ならびにそれが個人のパーソナリティ特性とどう関連 しているのかを検討することであった。領域別コンピテンス, 競争心, 情緒性のどのパーソナリティ特性が 社会的比較によって生じる感情や行動に強く影響を及ぼすのかを検討するために，3つのパーソナリティ特 性を説明変数に, 社会的比較の結果下位尺度を各々基準变数とする重回帰分析を学年別に行った。本研究の 結果より, 社会的比較を行った後に, その個人に生じる感情や行動は, パーソナリティ特性や発達段階に応 じて異なることがわかった。小学生（4 年生ならびに 6 年生）においては, 領域別コンピテンスが特に, 社 会的比較によって生じる感情や行動之強く関連していた。一方, 中学 2 年生においては, 競争心が社会的比 較によって生じる感情や行動に影響を及ぼしていた。

キーワード: 社会的比較, 発達的変化, パーソナリティ特性

\section{問題と目的}

Festinger (1954) が提唱した社会的比較 (social comparison) は「自分と他者とを比較することの 総称」と定義される。Festinger (1954) が社会的比 較過程理論を提唱してから, 半世紀が過ぎようと しているが，その間に社会的比較に関する研究は 精力的に行われ, その理論の妥当性を裏づける研 究が蓄積されている一方, 近年では, 社会的比較 が自己査定や自己高揚など，様々な機能に役立つ ことも指摘されている (e.g., Butler, 1992; Taylor \& Lobel, 1989)。

1) 本研究にご協力いただきました小・中学校の諸先生 ならびに児童・生徒の皆様に心より御礼申し上げま す。また，本論文の作成におきましてご助言，ご示 唆をいただきました查読者の方々に梁く感謝申し上 げます。
このように Festinger (1954) の理論は, 多くの実 証的研究を生み出しているが, Festinger の社会的 比較過程理論をめぐる諸知見の大部分は, 青年の しかも大学生という非常に限られたサンプルを対 象としたものであり, 大学生以外の発達段階にお いて妥当性を有するかについてや社会的比較の発 達過程については, ほとんど検討されないままに 経過してきた（高田，1990）。

子どもを対象とした社会的比較に関する研究の 多くは, あっぱら, 様々な機能をむつ社会的比較 がいつ頃から生起するのかといった, 社会的比較 が開始される発達上の時期を検討したもの (e.g., Butler \& Ruzany, 1993) であり（レビューとして, 高田, 1987, 2004), 社会的比較が行われた後の影 響についてはこれまで焦点が当てられてこなかっ た(Blanton, Buunk, Gibbons, \& Kuyper, 1999)。こ れは日常場面に打ける社会的比較について特にそ 
うである。社会的比較は, 学校のクラス環境にお いて頻繁に観察される行動である(Frey \& Ruble, 1985)にもかかわらず，児童・生徒における社会 的比較の影響については，これまで研究がされて こなかった(Huguet, Dumas, Monteil, \& Genestoux, 2001)。

しかし近年，こういった現状を踏まえて，子ど あを対象にした社会的比較の影響に関する実証的 研究が増えている。例えば, Blanton et al. (1999) や Huguet et al. (2001) は, 中学 1 年生が自分より 屯幾分学業成績の良いクラスメイトと自分の学業 成績を比較する傾向があること，こうした成績の 高いクラスメイトと社会的比較をする傾向が，個 人の学業成績の向上を予測することを見いだして いる。さらに，外山（2006）は，中学 1 年生の学 業成績の向上には，比較をしている友人の学業成 績と本人の学業コンピテンスの相互作用的な影響 が見られ，日頃学業成績が高い友人と比較をして いる人のうち, 学業コンピテンスが高い人に限っ て学業成績が向上することを見いだしている。

また，外山 (1999) は，小学校高学年児に対し て, 仮想上の友達の遂行（学業成績, 運動能力な ど）が自分のそれよりも高い状態（上方比較）の 物語を読ませ, その時の感情や行動を自由記述さ せた。その結果，子どもの中には，“自己向上の 努力”というポジティブな行動につながるものも いれば，“友達への廐妬”や“劣等感”というネ ガティブな感情を抱くものや “努力の放棄” や “友達への攻撃”といったネガティブな行動につ ながるものむいた。このように，社会的比較とり わけ上方比較の影響は必ずしも一方向によるもの ばかりではなく，そこにはパーソナリティ特性や 比較の対象など様々な要因が関わってくるものと 考えられる（Buunk, Collins, Taylor, Van Yperen, \& Dakof, 1990; Hemphill \& Lehman, 1991; 高田, 1981)。

本研究では, 小学 4 年生, 6 年生ならびに中学 2 年生を対象にして, 社会的比較の発達的变化に
ついて検討することを目的にした。より具体的に は，社会的比較を行った後に，その個人に生じる 感情や行動（以後 “社会的比較の結果”之記す） が発達的によ゙のように变化するのかを検討するこ と，および社会的比較の結果に影響を及ぼす要因 としてパーソナリティ特性に焦点を当て, どのよ うなパーソナリティ特性が社会的比較の結果によ゙ のように影響を及ぼすのかについて発達的に検討 することにした。社会的比較の発達過程に関する 研究の多くは, 幼児・児童 (特に低学年) や大学 生以降（e.g., 高田，1990）を対象にしたものであ る。これはひとえに, 既述したように子どもの社 会的比較の生起の時期を探ることや, 青年期（主 に大学生）における自己概念の形成のメカニズム としての社会的比較の役割を探ることに焦点が当 てられてきたことに严するものと考えられる。一 方, 児童期の高学年から大学生に上がるまでの社 会的比較の発達的变化についての実証的研究はほ とんどみられない。しかし，この時期は自己意識 の形成や社会的認知の発達が著しい時期でああり (Rholes, Newman, \& Ruble, 1990), 自己評価にお ける社会的比較が可能になる (Ruble, 1983) と考え られている小学 4 年生以降を対象にして, 社会的 比較の発達的变化を検討することは, 非常に意義 深いと考えられる。

社会的比較の結果に影響を及ぼすであろうパー ソナリティ特性としては, “情緒性（神経症傾 向)”，“競争心”ならびに“コンピテンス”を取 りあげることにした。情緒性は, 大学生を対象と した研究において, 社会的比較志向性 (social comparison orientation : 社会的比較に従事する 傾向）との間に強い関連性が見いだされており (Gibbons \& Buunk, 1999), 社会的比較の結果に影 響を及ぼすパーソナリティ特性であると考えられ る。

また，外山・伊藤 (2001) は, 小学生においては 周りの友達に負けたくないという競争意識から社 会的比較を行う児童が多いことを報告しており， 
人と競い合うことや勝ち負けへの感受性が高い競 争心というパーソナリティ特性が社会的比較の結 果に影響を及ぼすことが考えられる。

コンピテンスとは，“認知された有能さ(Harter, 1985)”のことであるが，コンピテンスと類似した 概念である自尊感情 2) と社会的比較の関連性につ いては, 主に大学生を対象とした実証的研究が行 われており, 一般的に自尊感情が低い人ほど, 社 会的比較行動に従事しやすいという結果が得られ ている (e.g., Gibbons \& Buunk, 1999; Wayment \& Taylor, 1995)。また, 外山・伊藤 (2001) の結果で は, 児童においては, 自尊感情の高低で社会的比 較を行う頻度に差は認められなかったが，社会的 比較を行う機能が異なることがわかった。すなわ ち, 自尊感情の高い人が自己向上のために社会的 比較を行う傾向があるのに対して, 自尊感情の低 い人は, 自分の劣等さを再確認するために他者之 比較を行い, その結果, さらに自己に対してネガ ティブな感情を抱くという悪循環に陥っていた。 このような知見から，コンピテンスというパーソ ナリティ特性が社会的比較の結果に影響を及ぼす と考えられる。

\section{方法}

\section{被調査児}

小学 4 年生 110 名（男子 57 名, 女子 53 名), 6 年生 108 名（男子 66 名, 女子 42 名), ならびに 中学 2 年生 144 名（男子 78 名, 女子 66 名）の計 362 名（男子 201 名, 女子 161 名)。このうち, い ずれの尺度にも欠損值のなかった小学 4 年生 103 名（男子 53 名, 女子 50 名), 6 年生 102 名（男 子 63 名, 女子 39 名), ならびに中学 2 年生 141 名（男子 76 名, 女子 65 名）の計 346 名（男子 192 名, 女子 154 名）が分析の対象とされた。

2) コンピテンスは自尊感情の概念に似ているが, 有能 さを漠然と測定するのではなく, いくつかの領域に 分けて測定しょうとしている点, 動機づけ面を強調 している点で自尊感情とは異なる（桜井, 1999）。

\section{質問紙}

以下の尺度から構成された。

(1) 社会的比較の対象/相手に関する質問紙な らびに社会的比較の結果に関する質問紙

まず，小学 4, 6 年生においては，日頃よく比 較する友達の名前を 1 人書加せ ${ }^{3)}$, 中学 2 年生に おいては，日頃よく比較する友達を 1 人思い浮か べるように教示した。

(a) 社会的比較の対象/相手に関する質問紙 どのような対象をその友達と比較するのかにつ いて，予備調査の結果に基づいて設定した 5 領域 （勉強，スポーッ，性格，外見〔ルックス〕，友人 関係）の中から 1 つ選んであらった。比較する対 象が選択肢の中にない場合には, 自由記述しても らった。そして, 選択してもらった領域において, 比較する友達がどのような相手であるのかを“自 分より優れている（上である）“ “自分と同じくら いである”“自分より劣っている(下である)”の 3 つの中から 1 つ選んであらった。

(b) 社会的比較の結果に関する質問紙（Table 1 参照)

その友達と比較した後によ゙のような気持ちに なったり，ぞういうことをしたりするのかを，予 備調査の結果に基づいて作成された 27 項目に対 して 5 段階評定（1. いいえ，2. どちらかといえ ばいいえ，3．どちらともいえない，4. どちらか といえばはい，5，はい）で回答を求めた。

(2) 領域別コンピテンス尺度

上記の社会的比較の対象の領域である勉強領域 (項目例 “勉強ができると思いますか”), スポー ツ領域（項目例“運動神経がいいと思いますか”), 友人関係領域 (項目例“友達がたくんさんいると 思いますか”）に打けるコンピテンスは，桜井 (1992) の児童用コンピテンス尺度項目を用いた。 また，性格領域（項目例“優しいと思いますか”）,

3) 質問紙終了後に, 書いてもらった友達の名前を消し ゴムで削除するように教示した。 
外見領域（項目例“自分の顔がかっこいい〔かわ いい〕と思いますか”）に拈けるコンピテンスは, 独自に作成した。各領域 4 項目ずつの計 20 項目 で構成されており，5段階評定（1５点）で回答 を求めた。

\section{（3）情緒性尺度}

曽我 (1999) による 5 因子性格検査 (FFPC) の情 緒性因子を用いた。情緒性とは“ストレスや脅威, あるいは他人の思惑に対して敏感で，緊張や不安 が強い。何事にも自信がなく落ち込みやすい傾向” であり，項目例としては，“人から見られている と落ち着かない”“何をしてあ，うまくいかないよ うな気がする”が挙げられる。8 項目で構成され ている。 3 段階評定（1 3 点）で回答を求めた。

（4）競争心尺度

Matthews (1980) の競争心尺度の翻訳版（大 㴊・佐藤，1991）を子どあ用に修正して用いた。 8 項目で構成されており， 5 段階評定（1～5 点） で回答を求めた。項目例としては, “負けず嫌い である”“何でも，楽しむことよりも勝つことの方 が大切である”が挙げられる。

\section{手続き}

上記の質問紙が 2 学期（10月）に実施された。 調査はクラス単位で行われ, 担任教師が質問項目 を読みあげて被調査児に回答させる強制速度法を 採用した。

\section{倫理的配慮}

調査に先立ち, 教頭, 学年主任および担任教師 から, 調査内容についてのインフォームド・コン セントを得た。調査は無記名方式で, 学校の成績 とは関係がないこと, 答えた内容が先生や友達あ るいは家族に洩れることは絶対にないことを フェースシートに明記するとともに，担任教師よ り教示してもらった。

\section{結果と考察 ${ }^{4)}$}

\section{（1）社会的比較の相手}

社会的比較の相手においては, “自分より優れ
ている（上である）”が 67 名 (19.4\%), “自分と同 じくらい”が 270 名 (78.0\%)，そして“自分より 劣っている(下である)”が 9 名 (2.6\%) であった。 Festinger (1954) は, 比較する相手としては, 自分 と類似した他者が一般的に好まれることを命題と しているが，本研究の被調查者においても自分と 同じくらいの相手と比較する傾向が見られた。ま た，児童・生徒においては自分より劣っている人 との比較である下方比較はほとんど見られないこ とがわかった。同様の結果は, 外山・伊藤 (2001) においても見られている。なお，社会的比較の結 果は, 社会的比較の方向性（上方比較なのか下方 比較なのか）によって異なってくることが考えら れるため (e.g., Buunk, Van Yperen, Taylor, \& Collins, 1991; Lockwood \& Kunda, 1997; Taylor, Wayment, \& Carillo, 1996), 以降の分析において は，比較する相手として“自分よりも劣っている (下である)”を選んだ 9 名は分析から除外した。 よって, 有効回答数は 337 名となり, 今後の分析 における社会的比較の相手は, 自分と同じくらい かそれ以上ということになった。

\section{(2) 社会的比較の対象と領域別コンピテンスの関} 係

社会的比較の対象（勉強，スポーツ，性格，外 見〔ルックス〕，友人関係）の内訳を見ると，勉 強が 98 名 (29.1\%), スポーツが 98 名 (29.1\%), 性 格が 93 名 (27.6\%), 外見が 31 名 (9.2\%), そして 友人関係が 15 名 $(4.5 \%)$ であった。先行研究（外 山，1999）と一致して，児童・生徒においては， 勉強, スポーツ, 性格が比較対象となることが多 いことがわかった。なお，比較対象として自由記 述をした 2 名においては, 分析から除外した。 よって，有効回答数は 335 名となった。

次に, 比較対象として勉強を挙げた“勉強群 $(n=98) ”$ 之勉強以外を比較対象に挙げた“勉強以

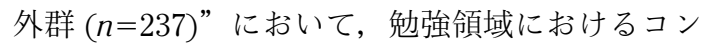

4) 本研究の分析には, SPSS (ver. 11.0)を使用した。 
ピテンス得点に差が見られるのかどうかを $t$ 検定 で検討したところ，“勉強群” $(M=11.74, S D=4.13)$ のほうが “勉強以外群” $(M=10.89, S D=3.12)$ より 屯有意に得点が高かった $(t=2.01, p<.05)$ 。同様の 手続きを用いて検討したところ, “スポーツ群 $(n=98) ”(M=13.29, S D=4.71)$ のほうが “スポーツ 以外群 $(n=237) ”(M=10.48, S D=4.81)$ よりあス ポーツ領域におけるコンピテンス得点が高く $(t=4.78, p<.01), “$ 外見群 $(n=31) ”(M=10.87$, $S D=3.99)$ が “外見以外群 $(n=304) ”(M=9.39$, $\mathrm{SD}=3.89)$ よりも外見領域におけるコンピテンス得 点が高かった $(t=1.98, p<.05)$ 。また，有意水準で はあったが, 性格領域におけるコンピテンス得点 は, “性格群 $(n=93) ”(M=12.80, S D=2.63)$ のほう が “性格以外群 $(n=242) ”(M=12.11, S D=3.08)$ よ りも高かった $(t=1.89, p<.10) 。 一$ 方, 友人関係領 域におけるコンピテンス得点においては, “友人 関係以外群 $(n=320) ”(M=12.79, S D=3.29)$ のほう が, “友人関係群 $(n=15) ”(M=9.57, S D=5.17)$ よ りも有意に高かった $(t=3.48, p<.01)$ 。

以上の結果より, 勉強, スポーッ, 性格, そし て外見に打いては，その領域に自信があってコン ピテンスの高い子どもがそれらの領域を比較対象 としていることがわかった。このことより，児 童・生徒における比較行動の背景には, 自己向上 動機が作用しているあのと示唆される。つまり, その領域に自信があってコンピテンスが高い者が, 自分と同じくらいの友人あるいは自分よりも優れ た友人と比較することで，友人をしのごうとする 向上性の圧力 (Festinger, 1954) が作用するむの之 考えられる。友人関係においては, その領域にお けるコンピテンスが低い人が比較することがわ かった。友人関係においては, それを比較対象之 している人数自体が少ないため（全体の $4.5 \%$ ), ここでの解釈は控える。

\section{（3）社会的比較の結果についての因子分析}

社会的比較の結果の 27 項目に抢いて, 学年別 による因子分析（最尤法 $\rightarrow$ プロマックス回転）を
行った。固有值の減衰率および因子の解釈可能性 を考慮した結果，いずれも 6 因子解が妥当との結 論を得た。また，いずれの学年においてもほぼ同 一の因子構造が得られた ${ }^{5)}$ 。Table 1 には, 全学年 を対象に同様の因子分析を行った結果が示されて いる。

第 1 因子には，落ち込んだ，泣きたくなった， などの項目が高い負荷量を示していることから “自己卑下”之命名した。第 2 因子には，その人 と話さなくなった，その人のことを無視したなな どの項目が高い負荷量を示していることから“回 避的行動”之命名した。第 3 因子には, その人と よく話すようになった，その人のことをほめた， などの項目が高い負荷量を示していることから “接近的行動” と命名した。そして, 第 4 因子に は，あっと頑張ろうと思った，やる気がでた，な どの項目が高い負荷量を示していることより“自 己向上”之命名した。第 5 因子には，何もしな かった，なんとも思わなかった，などの項目が高 い負荷量を示していることより “無力的行動” と 命名した。最後に, 第 6 因子には, 自分の方が 勝ったと思った，うれしくなった，などの項目が 高い負荷量を示していることから“自己高揚” と 命名した。“自己卑下”, “自己向上”, “自己高揚” は社会的比較を行った後に，その個人に生じる感 情で, “回避的行動”, “無力的行動”, “接近的行 動”は社会的比較を行った後に，その個人に生じ る行動とおおまかに分類できる。

因子分析の結果に基づき, 各因子に高い負荷量 を示す項目（Table1の枠で囲まれた項目）で下位 尺度を構成した。次に, 尺度の内的一貫性を検討 するため, Cronbachの $\alpha$ 係数を算出した結果, 自己卑下で.83, 回避的行動で.89, 接近的行動 で.77, 自己向上で.87, 無力的行動で.69, そして

5）ただし，小学校 4 年生はやや不安定な因子構造で, 2 つの因子に高い負荷量を示す項目が 2 項目ほどあっ た。因子構造は小学校 6 年生ならびに中学校 2 年生 と同様であった。 
Table 1 社会的比較の結果の因子分析の結果（全体）

\begin{tabular}{|c|c|c|c|c|c|c|c|c|}
\hline & \multirow[b]{2}{*}{$M$} & \multirow[b]{2}{*}{$S D$} & \multicolumn{6}{|c|}{ 抽出因子 } \\
\hline & & & I & II & III & IV & $\mathrm{V}$ & VI \\
\hline \multicolumn{9}{|l|}{ 自己卑下 $(\alpha=.83)$} \\
\hline 落ち込んだ & 1.82 & 1.34 & .78 & -.03 & -.17 & .28 & -.02 & -.06 \\
\hline 泣きたくなった & 1.71 & 1.17 & .77 & -.03 & -.12 & -.02 & -.20 & .18 \\
\hline ムシャクシャした & 1.91 & 1.20 & .71 & .01 & -.08 & .04 & .05 & -.08 \\
\hline むなしくなった & 1.77 & 1.30 & .67 & .03 & .10 & -.07 & .06 & -.07 \\
\hline みじめになった & 2.02 & 1.34 & .66 & .00 & .00 & .02 & .06 & -.07 \\
\hline 比べたことを後悔した & 1.81 & 1.20 & .62 & -.10 & .06 & -.11 & .18 & .03 \\
\hline その人をうらやましく思った & 2.65 & 1.62 & .44 & .01 & .20 & -.12 & -.08 & -.11 \\
\hline \multicolumn{9}{|l|}{ 回避的行動 $(\alpha=.89)$} \\
\hline その人と話さなくなった & 1.49 & .97 & .03 & .92 & -.01 & .00 & .01 & .04 \\
\hline その人のことを無視した & 1.43 & .91 & .01 & .91 & -.01 & .05 & .04 & -.03 \\
\hline その人のことをバカにした & 1.46 & .89 & -.11 & .87 & .05 & -.02 & .03 & -.05 \\
\hline \multicolumn{9}{|l|}{ 接近的行動 $(\alpha=.77)$} \\
\hline その人とよく話すようになった & 3.30 & 1.23 & -.09 & -.04 & .68 & -.07 & -.03 & .12 \\
\hline その人とむっと仲良くなった & 3.82 & 1.67 & -.09 & -.06 & .58 & .09 & -.12 & -.02 \\
\hline その人のことを目標にした & 3.33 & 1.59 & .09 & .03 & .58 & .17 & .13 & -.06 \\
\hline その人のことをほめた & 2.72 & 1.34 & .10 & -.04 & .57 & -.13 & -.12 & -.05 \\
\hline 前よりあその人と比べた & 2.58 & 1.37 & .02 & .30 & .40 & .07 & -.18 & -.01 \\
\hline \multicolumn{9}{|l|}{ 自己向上 $(\alpha=.87)$} \\
\hline あっと頑張ろうと思った & 3.94 & 1.38 & .01 & .00 & -.03 & .74 & .11 & -.12 \\
\hline やる気がでた & 4.21 & 1.10 & -.03 & .03 & .12 & .58 & .06 & .11 \\
\hline 負けたくないと思った & 3.81 & 1.32 & .10 & .07 & -.10 & .48 & -.04 & .19 \\
\hline あきらめようと思った & 1.94 & 1.30 & .21 & .06 & .12 & -.43 & .23 & .09 \\
\hline その人を見習いたいと思った & 3.35 & 1.40 & .10 & -.12 & .30 & .40 & -.04 & -.19 \\
\hline \multicolumn{9}{|l|}{ 無力的行動 $(\alpha=.69)$} \\
\hline 何むしなかった & 2.40 & 1.55 & .02 & .07 & -.14 & .11 & .76 & -.04 \\
\hline なんとも思わなかった & 2.87 & 1.67 & -.17 & -.03 & -.11 & .00 & .53 & .02 \\
\hline 考えないようにした & 2.10 & 1.31 & .15 & .28 & -.02 & .03 & .44 & .04 \\
\hline 仕方がないと思った & 2.72 & 1.52 & .27 & -.10 & .25 & -.05 & .38 & -.07 \\
\hline \multicolumn{9}{|l|}{ 自己高揚 ( $\alpha=.71)$} \\
\hline 自分の方が勝ったと思った & 2.70 & 1.18 & .08 & .00 & -.03 & -.02 & -.08 & .79 \\
\hline うれしくなった & 3.00 & 1.10 & -.08 & .00 & .29 & .05 & .11 & .59 \\
\hline 自分に自信がついた & 3.52 & 1.33 & -.11 & -.13 & .11 & .40 & .09 & .45 \\
\hline
\end{tabular}

注. $n=335$.

自己高揚で.71であった。一応満足し得る内的一 貫性が見られたが， $\alpha$ 係数が低い下位尺度に対し ては，項目数を増やすなどの処置を行い，今後は より内的一貫性の高い尺度への改善が望まれる。

\section{(4) 社会的比較の結果の発達的変化}

学年別, 性別による「社会的比較の結果」6つ の下位尺度の平均值と標準偏差を Table 2 に示し た。次に,「社会的比較の結果」の 6 つの下位尺 度と性別, 学年との関係を見るために, 各下位尺
度について, 性別(2)×学年(3) の二要因分散分析 を行った。なお, 本研究の多重比較には, すべて LSD 法（有意水準 5\%）を用いた。

まず，「接近的行動」および「回避的行動」に おいては, いずれの主効果, 交互作用も有意では なかった。「自己高揚」および「自己向上」にお いては, 学年においてのみ主効果が有意（順に, $F(2,334)=6.22, p<.01 ; F(2,334)=5.44, p<.01)$ で, 自己高揚においては小学 6 年生が中学 2 年生より 
Table 2 学年別, 性別による「社会的比較の結果」下位尺度の平均値 $(M)$ と標準偏差 $(S D)$

\begin{tabular}{|c|c|c|c|c|c|c|c|c|c|c|c|c|}
\hline & \multicolumn{4}{|c|}{ 小学 4 年生 $(n=95)$} & \multicolumn{4}{|c|}{ 小学 6 年生 $(n=101)$} & \multicolumn{4}{|c|}{ 中学 2 年生 $(n=139)$} \\
\hline & \multicolumn{2}{|c|}{ 男子 $(n=53)$} & \multicolumn{2}{|c|}{ 女子 $(n=42)$} & \multicolumn{2}{|c|}{ 男子 $(n=62)$} & \multicolumn{2}{|c|}{ 女子 $(n=39)$} & \multicolumn{2}{|c|}{ 男子 $(n=76)$} & \multicolumn{2}{|c|}{ 女子 $(n=63)$} \\
\hline & $M$ & $S D$ & $M$ & $S D$ & $M$ & $S D$ & $M$ & $S D$ & $M$ & $S D$ & $M$ & $S D$ \\
\hline 自己卑下 & 9.62 & 2.49 & 12.47 & 4.29 & 14.23 & 5.76 & 14.59 & 6.94 & 13.35 & 6.61 & 16.05 & 8.00 \\
\hline 自己高揚 & 8.45 & 3.49 & 9.09 & 2.00 & 10.00 & 2.74 & 10.11 & 2.70 & 9.33 & 3.02 & 8.50 & 2.84 \\
\hline 自己向上 & 18.12 & 4.21 & 18.45 & 3.87 & 20.51 & 4.19 & 19.89 & 4.18 & 18.94 & 4.47 & 20.34 & 3.91 \\
\hline 接近的行動 & 14.67 & 5.41 & 16.06 & 4.24 & 16.64 & 3.81 & 16.05 & 5.00 & 15.48 & 4.83 & 15.63 & 5.29 \\
\hline 回避的行動 & 4.29 & 3.02 & 4.25 & 2.59 & 4.69 & 2.49 & 4.08 & 2.34 & 4.76 & 2.66 & 4.26 & 2.43 \\
\hline 無力的行動 & 7.74 & 3.04 & 11.25 & 3.68 & 11.56 & 4.20 & 11.13 & 4.51 & 9.30 & 3.65 & 9.59 & 3.95 \\
\hline
\end{tabular}

屯得点が有意に高く, 自己向上においては，小学 6 年生が小学 4 年生ならびに中学 2 年生よりも得 点が有意に高かった。

そして，「自己卑下」においては，性別 $(F(1,334)=7.86, p<.01)$, 学年 $(F(2,334)=10.71$, $p<.01)$ いずれの主効果も有意であった。性別では 女子の方が男子よりも有意に高い得点を示した。 学年の主効果について多重比較を行った結果, 小 学 4 年生が小学 6 年生ならびに中学 2 年生よりも 得点が有意に低かった。交互作用は有意でなかっ た。

最後に,「無力的行動」においては, 性別 $(F(1,334)=6.68, p<.05)$, 学年 $(F(2,334)=8.31$, $p<.01 ）$ いずれの主効果も有意で, 交互作用も有 意であった $(F(2,334)=7.56, p<.01)$ 。ここで, 性 別, 学年別のそれぞれで単純主効果の検定を行っ た。性別の単純主効果の検定では, 小学 4 年生 $(F(1,334)=21.37, p<.01)$ においてのみ女子が有意 に高い得点を示した。学年の単純主効果検定で は, 男子においてのみ有意で $(F(2,334)=12.86$, $p<.01)$, 小学 6 年生 $>$ 中学 2 年生 $>$ 小学 4 年生の 順に得点が有意に高かった。Figure 1 に「無力的 行動」における性別, 学年別の得点を示した。

以上の結果より, 社会的比較の結果, 女子は男 子よりも自己卑下的な感情を抱くことがわかった。 他者（親や先生）から比較される時にも, 女子は 男子よりも自己卑下的な感情を抱きやすいことが 報告されている（外山・伊藤，2001）が，社会的

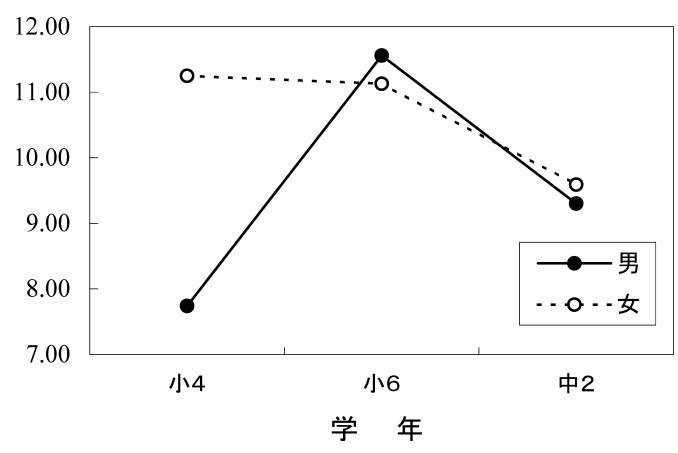

Figure 1 「無力的行動」における性別・学年別の平均 得点

比較をする, される両者において, 女子は男子よ りもネガティブな感情を抱きやすいことが示され た。

発達的にみると, 社会的比較の結果は, 小学 6 年生を境目に变化が見られることが多いようであ る。自己高揚的な感情は小学 6 年生を境目に減少 していた。自己卑下的な感情は，小学 6 年生にな ると急に高くなっていた。また，自己向上は小学 6 年生がどの学年よりあ高かった。さらに，無力 的行動においても，男子においてのみであるが, 小学 6 年生がどの学年よりも高かった。堂野・田 頭・土江 (1990) は児童期から青年期にかけての劣 等感の発達的变化を検討し, 小学 5 年生の時期が 大きな変動期・転換期であり, 心身ともに動摇し やすく不安定になりやすい発達段階であることを 指摘している。さらにこの時期は，自己意識の高 
まり（桜井， 1992）や，社会的認知の著しい発達 が見られる時期でもあり (Rholes et al., 1990), 社 会的比較の影響を被りやすい発達段階であると言 えるのかもしれない。

(5) 社会的比較の結果に及ぼすパーソナリティ特 性（領域別コンピテンス, 競争心, 情緒性） の影響

領域別コンピテンス，競争心ならびに情緒性の 記述統計量を Table 3 に示した。次に, 領域別コ ンピテンス, 競争心, 情緒性のどのパーソナリ ティ特性が社会的比較の結果に強く影響を及ぼす のかを検討するために，3つのパーソナリティ特 性を説明变数に，「社会的比較の結果」6つの下位 尺度を各々基準変数とする重回帰分析を学年別に 行った（Figure 2 参照)。領域別コンピテンス（以 下, “コンピテンス”と略す）は, 比較対象とし て選んだ領域におけるコンピテンス得点を用いた。

決定係数 $\left(R^{2}\right)$ について検討すると，小学 6 年生 ならびに中学 2 年生において回避的行動を基準変 数とした場合と中学 2 年生において無力的行動を 基準変数とした場合を除いて有意となった $\left(R^{2}=\right.$ .08 .31)。次に，標準偏回帰係数（パス係数）に ついて見ていく。まず小学 4 年生は, コンピテン スと社会的比較の結果が強く関連していることが わかった。コンピテンスの高い人は, 社会的比較 の結果, 自己高揚的な感情を抱き $(\beta=.55)$, 自己 向上を目指し $(\beta=.31)$, 接近的行動に従事し $(\beta=$

Table 3 領域別コンピテンス, 競争心ならびに 情緒性の記述統計量

\begin{tabular}{lrrc}
\hline & $M$ & $S D$ & $\alpha$ 係数 \\
\hline 領域別コンピテンス & & & \\
$\quad$ 勉強 & 10.98 & 3.46 & .82 \\
スポーツ & 11.27 & 4.90 & .90 \\
性格 & 12.28 & 2.94 & .77 \\
外見 & 9.55 & 3.86 & .81 \\
友人関係 & 12.76 & 3.27 & .67 \\
競争心 & 24.52 & 7.16 & .80 \\
情緒性 & 24.09 & 7.56 & .71 \\
\hline
\end{tabular}

注. $n=335$.
.36), 無力的行動に従事しない $(\beta=-.40)$ ことが示 された。また, 情緒性といったパーソナリティ特 性む社会的比較の結果に影響を及ぼしており，情 緒性の高い人は, 社会的比較の結果, 自己卑下的 な感情を抱きやすく $(\beta=.46)$, 自己向上は目指さ ず $(\beta=-.21)$, 回避的行動をとりやすい傾向が見ら れた $(\beta=.39)$ 。らに, 競争心が自己向上 $(\beta=.29)$ および無力的行動 $(\beta=.32)$ と関連していた。

次に小学 6 年生においては, 小学 4 年生と同様 に,コンピテンスが社会的比較の結果と強く関連 しており，回避的行動を除くすべての社会的比較 の結果と関連していた。また, 情緒性が接近的行 動 $(\beta=-.26)$ と競争心が自己卑下 $(\beta=.22)$ 抢よび 自己高揚 $(\beta=.33)$ と関連していた。

最後に中学 2 年生においては, 競争心という パーソナリティ特性が社会的比較の結果に影響を 及ぼすことが明らかになった。それは，競争心の 高い人は, 社会的比較の結果, 自己卑下 $(\beta=.16)$ や自己高揚 $(\beta=.18)$ の感情を抱きやすく, 自己向 上を目指し $(\beta=.28)$, 相手に接近する $(\beta=.29)$ とい うものであった。また，コンピテンスが自己高揚 $(\beta=.29)$ と, 情緒性が自己卑下 $(\beta=.39)$ と関連し ていた。

本研究の結果より, 小学生（4 年生ならびに 6 年生）においては, “コンピテンス”といったパー ソナリティ特性が特に社会的比較の結果に大きく 影響を与えていた。それは，コンピテンスの高い 者は社会的比較を行った後で，自分に自信がつい たり，比較した相手に近づきさらに努力しようと 思い, 決して無気力にはならないという結果だっ た。外山（2006）は，友達との学業成績における 社会的比較が学業成績の向上に結びつくのに，コ ンピテンスが重要な要因であることを指摘してい る。社会的比較が行われた時にポジティブな結果 が生じるためには，子どものコンピテンスを高め るような介入が重要になってくるものと考えられ る。

中学 2 年生においては, “競争心”が社会的比 


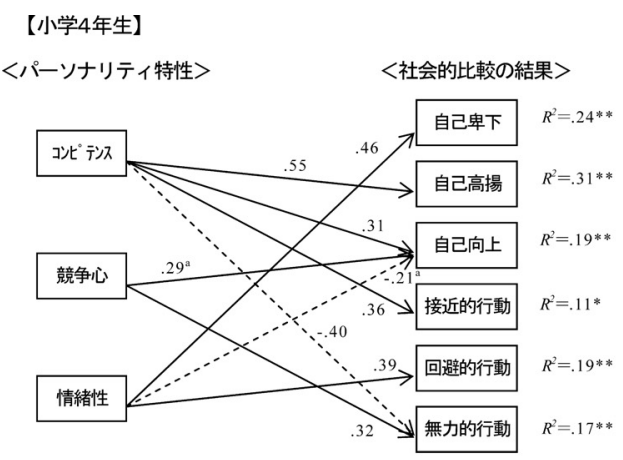

\section{【小学6年生】}

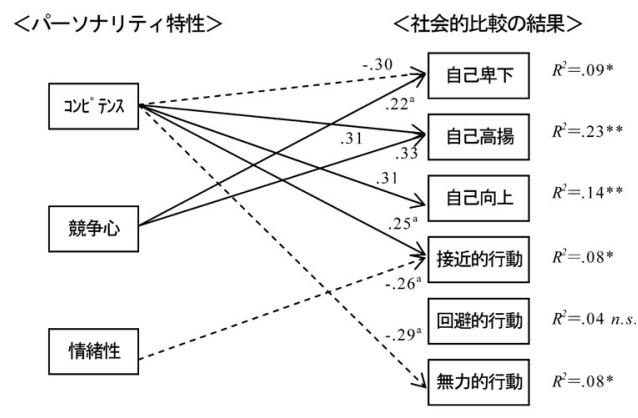

【中学2年生】

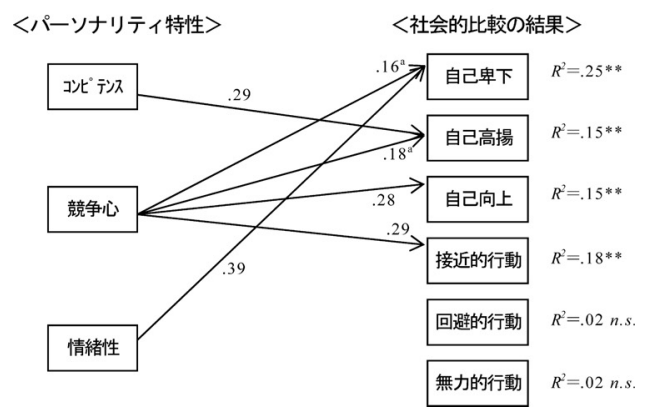

Figure 2 学年別におけるパス・ダイアグラム

注 1. 数值は標準偏回帰係数を表す．数值に $\mathrm{a}$ が記されているもののみ $5 \%$ 水準で有意で, それ以外はすべて $1 \%$ 水準で 有意である。

注 2. 実線は正のパス，点線は負のパスである。

注 $3 . * p<.05, * * p<.01$.

較の結果に対して重要な役割を果たすことがわ かった。中学校は,これまでの小学校との環境と は異なり, 生徒により挑戦的な環境を提供する場 である。例えば学習場面においては, 定期試験と いう形での校内一斉テストによって学習の評価が 行われるし, 運動場面においても, 部活動といっ た同じ目標に取り組む仲間との競争場面に多々曝
されることになる。そうした競争的な文脈が増え てくる中学生においては, “競争心”というパー ソナリティ特性が社会的比較の結果に影響を及ぼ す力が大きくなってくるあのと考えられる。

ところで, その競争心が社会的比較の結果に与 える方向は一様ではなく, 例えば “自己高揚” と いったポジティブな感情に結びっくものと“自己 
卑下”といったネガティブな感情に結びっくもの があった。どちらの感情につながるのかには，比 較相手之の遂行水準の差の大きさや別のパーソナ リティ特性など様々な要因が絡んでくるものと考 えられ，今後詳細な解明が望まれる。

また，中学 2 年生においては，社会的比較を 行った後の行動（接近的行動, 回避的行動, 無力 的行動）に影響を及ぼすパーソナリティ特性は, 競争心のみであり, しかも行動の中でも接近的行 動のみへの影響であった。年齢が上がるにつれて, パーソナリティ特性が直接的に社会的比較が行わ れた後の行動に影響を及ぼすのではなく，そこに は別の要因が媒介 (mediate) あるいは調整 (moderate)している可能性が考えられる。本研究は一時 点における質問紙調查であるため, 社会的比較に よって生じる感情と行動を並列的に扱ったが，例 えば，パーソナリティ特性 $\rightarrow$ 感情 $\rightarrow$ 行動といった 感情と行動に時間的因果的系列性を仮定できる可 能性屯考えられる。今後は, 縦時的な変化を追跡 する縦断的研究ならびに実験的手法を導入した研 究を試みるとともに，要因間の構造をより適切に とらえたモデルを提出し，その妥当性について実 証的に検討し，社会的比較の結果に及ぼす様々な 要因の影響についてより明らかにしていく必要が ある。

ところで，小学 6 年生ならびに中学 2 年生にお いては，回避的行動に影響を及ぼすパーソナリ ティ特性は, 本研究で取りあげたコンピテンス, 競争心ならびに情緒性の中においてはなかった。 相手のことを無視したりバカにしたりする回避的 行動は，いじめや攻撃行動に代表される子どもの 様々な問題行動へ結びっく恐れのあるあのであり, こうした問題行動を理解する上で社会的比較が重 要な鍵となる可能性む考えられる。例えば，上方 比較をする相手が自分にとって嫌いな人であった り，横柄な性格の持ち主であったりすると，その 相手に対する攻撃行動が増すことが指摘されてい る (Smith, 2000)。今後は, 社会的比較が行われた
場合に，どのような文脈でどのようなプロセスを 経て回避的行動に結びつくのか詳細に検討してい くことが早急に望まれる。そうすることで，比較 する友人の優れた遂行によって, 多少なりと屯自 己の相対的劣位の知覚が生じても (Tesser, Campbell, \& Smith, 1984), どうすれば建設的な行動を とることができるのかといった教育的介入を提供 することができよう。

以上, 本研究より, 社会的比較を行った後に個 人に生じる感情や行動は，パーソナリティ特性や 発達段階に応じて異なることがわかった。しかし， 本研究では, 社会的比較の結果に影響を及ぼす要 因として，年齢とコンピテンス，競争心そして情 緒性のパーソナリティ特性のみしか扱っていない。 また, 本研究では, 社会的比較の方向性として下 方比較は扱っていないため, 今後は, 社会的比較 の方向性（上方比較 V.S.下方比較）についても検 討を加える必要がある。

さらに, 社会的比較の結果は, 学校やクラスの 風土などによって異なってくる可能性が考えられ る。例えば，競争や社会的比較を過度に強調する 学校やクラスにおいては, 社会的比較のネガティ ブな結果を被りやすくなるのかもしれない。本研 究は, ある地域の小・中学校 1 校でのサンプルに 基づいた調査であり, 今後は, 学校やクラスの環 境（e.g., 社会的比較に対する担任教師の規制）の 文化的要因などについても考慮していかなればな らない。また，“社会的比較の結果尺度”や“領 域別コンピテンス尺度” は, 本研究で独自に作 成・使用したものであり，その信頼性（時間的安 定性）や妥当性については検討されていない。今 後は，尺度の充実化屯急務であると考えられる。

冒頭のところで述べたように，日常場面におけ る社会的比較の影響を検討した研究は数少ない。 今後は上述したような課題について詳細に検討し ていきながら，子どもの社会的比較の影響につい て探っていきたい。 


\section{引用文献}

Blanton, H., Buunk, B. P., Gibbons, F. X., \& Kuyper, H. (1999). When better-than-others compare upward: Choice of comparison and comparative evaluation as independent predictors of academic performance. Journal of Personality and Social Psychology, 76, 420-430.

Buss, A. H. (1986). Social behavior and personality. New Jersey: Lawrence Erlbaum Associates.

（バス A. H. 大㴊憲一・佐藤公文 (1991). 第 4 章 社会的パワーを得るために一支配 大㴊憲一 (監訳), 対人行動とパーソナリティ 北大路書房 $\mathrm{pp}$. 77-110.)

Butler, R. (1992). What young people want to know when: Effects of mastery and ability goals on interest in different kinds of social comparison. Journal of Personality and Social Psychology, 62, 934-943.

Butler, R., \& Ruzany, N. (1993). Age and socialization effects on the development of social comparison motives and normative ability assessment in kibbutz and urban children. Child Development, 64, 532-543.

Buunk, B. P., Collins, R., Taylor, S. E., Van Yperen, N. W., \& Dakof, G. (1990). The affective consequences of social comparison: Either direction has its ups and downs. Journal of Personality and Social Psychology, 59, 1238-1249.

Buunk, B. P., Van Yperen, N. W., Taylor, S. E., \& Collins, R. L. (1991). Social comparison and the drive upward revised: Affiliation as a response to marital stress. European Journal of Social Psychology, 21, 529-546.

堂野佐俊・田頭穂積・土江禎子（1990）。监童期の心理 的ストレスに関する一研究 広島文教女子大学紀要,

25, 165-176.

Festinger, L. (1954). A theory of social comparison process. Human Relations, 7, 117-140.

Frey, K. S., \& Ruble, D. N. (1985). What children say when the teacher is not around: Conflicting goals in social comparison and performance assessment in the classroom. Journal of Personality and Social Psychology, 48, 550-562.

Gibbons, F. X., \& Buunk, B. P. (1999). Individual differences in social comparison: Development of a scale of social comparison orientation. Journal of Personality and Social Psychology, 76, 129-142.

Harter, S. (1985). Manual for the self-perception profile for children. Denver, CO: University of Denver.
Hemphill, K. J., \& Lehman, D. R. (1991). Social comparisons and their affective consequences: The importance of comparison dimension and individual difference variables. Journal of Social and Clinical Psychology, 10, 372-394.

Huguet, P., Dumas, J. F., Monteil, J. M., \& Genestoux, N. (2001). Social comparison choice in the classroom: Further evidence for students' upward comparison tendency and its beneficial impact on performance. $E u$ ropean Journal of Social Psychology, 31, 557-578.

Lockwood, P., \& Kunda, Z. (1997). Superstars and me: Predicting the impact of role models on the self. Journal of Personality and Social Psychology, 73, 91-103.

Matthews, K. A. (1980). Measurement of type A behavior in children: Assessment of children's competitiveness, impatience-anger, and aggression. Child Development, 51, 466-475.

Rholes, S., Newman, L., \& Ruble, D. N. (1990). Understanding self and other: Developmental and motivational aspects of perceiving persons in terms of invariant dispositions. In E. T. Higgins, \& R. M. Sorrentino (Eds.), Handbook of motivation and cognition: Foundations of social behavior. Vol. 2. New York: Guilford Press. pp. 369-407.

Ruble, D. N. (1983). The development of social comparison processes and their role in achievement-related selfsocialization. In E. T. Higgins, D. N. Ruble, \& W. W. Hartup (Eds.), Social cognition and social development. Cambridge: Cambridge University Press. pp. 134-157.

桜井茂男（1992）。 小学校高学年生における自己意識の 検討 実験社会心理学研究，32, 85-94.

桜井茂男（1999）。 子どあのやる気と社会性 風間書房 Smith, R. H. (2000). Assimilative and contrastive emotional reactions to upward and downward social comparisons. In J. Suls, \& L. Wheeler (Eds.), Handbook of social comparison: Theory and research. New York: Kluwer Academic/Plenum Publishers. pp. 173-200.

兽我祥子（1999）。小学生用 5 因子性格検査 (FFPC) の 標準化 心理学研究, 70, 346-351.

高田利武 (1981). 対人恐怖と社会的比較 年報社会心 理学, 22, 201-218.

高田利武 (1987). 社会的比較の発達過程に就て一文 献的考察——群馬大学教育学部紀要人文・社会科 学編, 36, 349-362.

高田利武 (1990). 社会的比較—その発達過程— 三隅二不二・木下富雄 (編), 現代社会心理学の発展 
II ナカニシャ出版 pp. 96-119.

高田利武 (2004).「日本人らしさ」の発達社会心理学 ナカニシャ出版

Taylor, S. E., \& Lobel, M. (1989). Social comparison activity under threat: Downward evaluation and upward contacts. Psychological Bulletin, 90, 245-271.

Taylor, S. E., Wayment, H. A., \& Carillo, M. (1996). Social comparison, self-regulation, and motivation. In R. M. Sorrentino, \& E. T. Higgins (Eds.), Handbook of motivation and cognition. New York: Guilford Press. pp. 3-27. Tesser, A., Campbell, J., \& Smith, M. (1984). Friendship choice and performance: Self-evaluation maintenance in children. Journal of Personality and Social Psychol- ogy, 46, 561-574.

外山美樹（1999）。览童に打ける社会的比較の様態 筑 波大学発達臨床心理学研究, 11, 69-75.

外山美樹 (2006). 中学生の学業成績の向上に関する研 究——比較他者の遂行と学業コンピテンスの影響— 教育心理学研究, 54, 55-62.

外山美樹 ・伊藤正哉 (2001). 児童における社会的比較 の様態(2)—ーパーソナリティ要因の影響——筑波 大学発達臨床心理学研究, 13, 53-61.

Wayment, H. A., \& Taylor, S. E. (1995). Self-evaluation process: Motives, information use, and self-esteem. Journal of Personality, 63, 729-757.

- 2005.7.22 受稿, 2006.2.8 受理一

\title{
Children's Emotion and Behavior after Social Comparison: Age and Personality Differences
}

\author{
Miki TOYAMA ${ }^{1,2}$ \\ ${ }^{1}$ Japan Society for the Promotion of Science \\ ${ }^{2}$ Faculty of Humanities, Tokyo Seitoku University \\ The Japanese Journal of Personality 2006, Vol. 15 No. 1, 1-12
}

The purpose of the present study was to examine children's emotion and behavior that arose after social comparison, and to find personality correlates of such emotion and behavior. Participants were elementary school children, grades 4 and 6, and junior high school students in their second year. Multiple regression analyses were conducted in order to predict children's emotion and behavior after social comparison with personality variables as predictors. The variables used for prediction were specific competence, competitiveness, and emotional instability. It was found that children's emotion and behavior after social comparison were different, depending on their developmental stage and personality. For elementary school children, social comparison-based emotion and behavior had a strong association with specific competence. In contrast, for junior high school students, it was competitiveness that was associated with the emotion and behavior.

Key words: social comparison, developmental change, personality, specific competence 